\title{
KAJIAN TEKNO-SOSIO-EKONOMIS PRAKTEK TITIP MUATAN DALAM REVITALISASI PERIKANAN TANGKAP
}

\author{
Elly Reswati dan Agus Heri Purnomo")
}

\begin{abstract}
ABSTRAK
Penelitian dilaksanakan pada tahun 2004 dengan tujuan mengkaji kemungkinan penerapan sistim titip muatan sebagai salah satu upaya revitalisasi usaha perikanan tangkap dengan pendekatan studi kasus pada lokasi-lokasi kasus meliputi Juwana (Pati), Cilacap dan Pekalongan. Data utama yang digunakan merupakan data primer, yang mencakup informasi variabel-variabel teknis dan finansial, dikumpulkan secara purposif melalui wawancara menggunakan daftar isian berstruktur. Responden dipilih berdasarkan teknik stratified random sampling, dimana pada setiap kasus dipilih kelompok-kelompok yang relevan. Analisis finansial dilakukan untuk melihat keuntungan yang diperoleh dari praktek titip sedangkan analisis deskriptif kualitatif dilakukan untuk memperbandingkan variasi teknis dari praktek titip di ketiga lokasi. Hasil menunjukkan bahwa praktek titip muatan dapat memperbaiki pendapatan yang terkait dengan kenaikan keuntungan hingga $90 \%$. Di Juwana, peningkatan laba kotor kapal penitip mencapai $(86 \%)$ /trip, bagi penerima titipan $(10 \%)$. Di Cilacap, peningkatan laba kotor kapal penitip mencapai $(67,5 \%) / t$ trip, bagi penerima titipan $(39,21 \%)$. Di Pekalongan peningkatan laba kotor kapal penitip mencapai $(35,1 \%) /$ trip, bagi penerima titipan, mengalami kerugian $(10,22 \%)$ /trip. Berdasarkan itu, praktek ini dapat dipertimbangkan untuk pengembangannya di tempat lain. Penelitian ini juga menunjukkan bahwa pengembangan praktek titip muatan di tempat lain dilakukan dengan penyesuaian yang mengacu pada kajian aspek teknis dan sosial setempat. $D i$ Juwana, praktek titip muatan dilakukan oleh nelayan dalam satu pemilik maupun pemilik yang berbeda, mekanisme pemindahan ikan menggunakan blong dengan cara merapatkan kapal penitip dengan kapal yang dititipi. Sebaliknya di Cilacap, hanya dilakukan oleh nelayan dalam satu pemilik dengan mekanisme pemindahan ikan tidak merapatkan kapal melainkan dibantu oleh kapal kecil yang menjadi media pemindahannya. Di Pekalongan sama dengan di cilacap, dilakukan dalam satu pemilik kapal, mekanisme pemindahan ikan sama dengan di Juwana.
\end{abstract}

\section{ABSTRACT: Techno-socio-economic assessment of entrusted-catch shipping for revita- lization of capture fishery. By: Elly Reswati and Agus Heri Purnomo}

This research was conducted in 2004 and aimed to assess the possibility of applying entrusted-catch shipping practices as a way to revitalize capture fishery. The approach adopted was the case study, which was based on data of three locatrions, namely Juwana (Pati), Cilacap dan Pekalongan, wherein such practices exist. Data used in the primary data consisting information on techical and financial variables, which were collected purposively through interviews using structured questionnaires. Respondents were selected based on the stratified random sampling technique, where in case a number of relevant groups were chosen. Financial analysis were conducted to portray the potential profit increase associated with the practice while qualitative deskriptive analysis was performed to compare technical variation that developed in the location as associated with local conditions. The result showed that the practice could increase profits of fishermen as high as $90 \%$. The increasing of gross benefit of carrier system at Juwana is up to 86 $\%)$ /trip and (10\%) for carrierer it self. Thus, the increasing of gross benefit of camier system at Cilacap is up to (67.5\%)/trip and (39.21\%) for carrierer itself. Meanwhile, the increasing of gross benefit of carrier system at Pekalongan is up to (35.1\%)/trip, but the carrierer gets of lost $(10.22 \%)$. Base on this, it was assumed that entrusted-catch fishing practices my be introduced to other places with some modification. The modifications are those that enable the practice to accommodate local constraints, including technical and social ones. In Juwana, practice of entrusted catchshipping conducted by fisherman in one owner or different owner, the mechanism of fish evacuation was used blong by closing entrusted ship to another ship. The other case in Cilacap, only conducted by fisherman in one owner, mechanism of fish evacuation did not closed ship but assisted by small ship (becoming evacuation media). In Pekalongan, the practice of entrusted catch-shipping conducted by one ship owner, mechanism of fish evacuation had the same ways as Juwana.

KEYWORDS: catch entrusting, revitalization of capture fishery, fishers' ncome

Peneliti pada Balai Besar Riset Sosial Ekonomi Kelautan dan Perikanan 


\section{PENDAHULUAN}

Gejala tangkap lebih yang diikuti peningkatan jarak tempuh rata-rata nelayan ke lokasi-lokasi penangkapan, menuntut respon yang tepat dari industri perikanan tangkap, sehingga penurunan kinerja yang berlanjut yang diakibatkannya dapat dihindarkan. Sebuah hasil penelitian terkait (Apriliani \& Purnomo, 2005), menunjukkan bahwa peningkatan jarak tempuh memaksa kapal-kapal purse seine berukuran 30-50 GT di Pantura menambah hari layar hingga 4-5 kali dan memunculkan dampak negatif multiaspek. Selain memperbesar proporsi pendaratan berkualitas rendah, penangkapan berjarak jauh tersebut terbukti menekan keuntungan usaha para nelayan secara signifikan. Selisih antara raman kotor dan biaya operasional menjadi semakin kecil karena rata-rata harga jual ikan yang rendah.

Relevansi dari respons tepat seperti dimaksud di atas bertambah besar sehubungan dengan kenaikan harga bahan bakar pendukung operasi penangkapan, yang cenderung terjadi secara konsisten dari waktu ke waktu. Terkait dengan kenaikan harga bahan bakar, kegiatan melaut di berbagai pangkalan nelayan skala kecil seperti Ciamis, Kendal, Kotabaru dan Medan menghentikan operasi (HNSI, 2005).

Salah satu bentuk respons potensial yang dapat dipertimbangkan oleh industri perikanan tangkap adalah kebijakan pengembagan sistem yang memungkinkan kapal untuk tidak terlalu sering kembali ke pangkalan untuk mendaratkan muatan (Suboko, 2005). Titip muatan, dimana kapal-kapal yang telah memperoleh sejumlah hasil tangkapan menitipkan hasil tangkapannya kepada kapal-kapal yang akan segera mendarat dapat dipandang sebagai salah satu bentuk solusi yang ditawarkan oleh Suboko (2005) tersebut. Melalui sistem seperti itu, diharapkan bahwa rentang waktu antara saat penangkapan ikan dan saat pendaratan dapat diperpendek. Dengan begitu, biaya operasi penangkapan dapat ditekan, proporsi pendaratan berkualitas baik dapat ditingkatkan, dan keuntungan usaha dapat diperbesar.

Sistem titip muatan sudah berjalan beberapa lokasi, misalnya Juwana, Cilacap dan Pekalongan, dengan beberapa variasi yang kemungkinan besar terkait dengan kondisi teknis, ekonomis dan sosial. Terlepas dari variasi tersebut, dapat diasumsikan bahwa telah dan tetap berlangsungnya praktek tersebut di lokasi-lokasi tersebut dikarenakan oleh adanya motif tertentu, yang kemungkinan besar adalah insentif ekonomi dalam bentuk efisiensi biaya operasi. Terkait dengan masalah tangkap lebih, perpanjangan hari layar, inefisiensi operasi penangkapan, penurunan kualitas pendaratan dan penurunan keuntungan usaha yang menjadi kecenderungan pada perikanan Indonesia, sistem yang dipraktekkan oleh para nelayan di lokasilokasi tersebut di atas membuka peluang untuk penggalian informasi lebih mendalam, yang dapat dijadikan dasar untuk merumuskan kebijakan yang secara tepat merespon munculnya berbagai permasalahan tersebut di atas.

Berdasarkan latar belakang tersebut diatas, penelitian sebagaimana dilaporkan dalam makalah ini ditujukan untuk mengkaji aspek profitabilitas dan teknis dari sistem titip muatan, dikaitkan dengan upaya penyehatan usaha perikanan tangkap.

\section{METODE}

Penelitian ini dilakukan dengan pendekatan studi kasus, dimana analisis didasarkan atas hasil pengamatan di lokasi-lokasi kasus yaitu Juwana, Cilacap dan Pekalongan. Lokasi-lokasi tersebut dipilih dengan pertimbangan bahwa masing-masing telah mempraktekkan sistem titip muatan dalam kondisi teknis yang berbeda; nelayan Juwana mempraktekkan sistem titip antar kapal purse seine berbeda armada, nelayan Pekalongan mempraktekkan titip muatan antar kapal purse seine dan gill net dalam satu armada, sedangkan nelayan Cilacap mempraktekkan titip muatan antar kapal long line. Kajian aspek teknis maupun finansial pada kondisi yang berbeda di lokasi-lokasi tersebut diharapkan mampu menggambarkan sebuah kesimpulan umum, yang dapat mendasari aplikasi secara general.

Data utama dalam penelitian ini adalah data primer, yang mencakup informasi mengenai variabelvariabel teknis dan finansial, yang dikumpulkan secara purposif melalui wawancara menggunakan daftar isian berstruktur. Responden dipilih berdasarkan teknik stratified random sampling (Nazir, 1985), yang diterapkan sebagai berikut: Untuk masing-masing kasus, dipilih kelompok-kelompok yang relevan dengan topik penelitian, misalnya kelompok nakhoda, pemilik (juragan), dan ABK. Kemudian, dari masing-masing kelompok tersebut, diambil beberapa responden secara acak untuk mewakili masing-masing kelompok tersebut. Informasi pelengkap (termasuk data sekunder) dikumpulkan pula dari narasumber penunjang, misalnya pengelola TPI dan staf Dinas Perikanan.

Data-data tersebut dianalisis untuk menjawab dua pertanyaan utama yaitu: (1) bagaimana kondisi teknis dimana varian-varian dari sisitem titip tersebut diterapkan di masing-masing lokasi kasus dan (2) 
seberapa besar sistem iersebut memberikan keuntungan bagi pengoperasian usaha penangkapan ikan. Untuk menjawab pertanyaan pertama, data dianalisis secara deskriptif kualitatif sedangkan untuk pertanyaan kedua, data diolah untuk melakukan analisis finansial (Hernanto, 1998; Sisdjatmiko, 1990; Riyanto, 1995); dalam hal ini, tambahan keuntungan dilihat dengan memperbandingkan laba kotor ${ }^{11}$ upaya penangkapan dengan dan tanpa penitipan muatan (hasil tangkapan).

\section{HASIL DAN BAHASAN}

\section{Aspek Teknis}

Analisis terhadap informasi teknis berikut ini mengarah pada sebuah kesimpulan umum bahwa titip muatan di ketiga lokasi secara teknis dimungkinkan oleh adanya kesesuaian antara kondisi teknis yang melingkungi operasi usaha penangkapan di lokasi-lokasi tersebut dengan pendekatan-pendekatan praktis yang dikembangkan oleh para nelayan. Misalnya, sebagaimana terjadi di salah satu lokasi, pemindahan ikan-ikan berukuran kecil dari kapal penitip ke kapal penerima titipan dapat terjadi karena didukung oleh dua faktor teknis berupa kondisi perairan yang relatif tenang sehingga kedua kapal dapat merapat dalam jarak yang cukup dekat dan adanya mekanisme praktis yang dikembangkan oleh nelayan yang memungkinkan terlaksananya pemindahan ikan secara efisien dan aman. Berikut adalah tinjauan lebih jauh mengenai aspek teknis untuk masingmasing lokasi kasus.

Di Juwana, sistem titip muatan berlangsung di kalangan nelayan purse seine, baik yang tergabung dalam armada yang sama maupun armada yang berbeda. Kondisi tangkap lebih (overfishing) justru secara teknis telah memungkinkan berlangsungnya praktek titip muatan antar kapal. Pada umumnya, kapal-kapal nelayan dalam kondisi perikanan tangkap lebih hanya mampu mendaratkan ikan kurang dari kapasitas palkanya, sehingga tersisa sejumlah ruang kosong yang dapat dimanfaatkan untuk menampung hasil tangkapan dari kapal lain. Bahkan dengan durasi trip diperpanjang seperti dilakukan oleh nelayan pada kondisi overfishing seperti sekarang ini, kapal dengan 4 palka hanya mampu mendaratkan ikan sejumlah satu palka sedang kapal dengan 8 palka hanya memanfaatkan 2 atau 3 palka di antaranya.

Terlepas dari adanya pra-kondisi mendukung tersebut di atas, ide penitipan ikan dari satu kapal penangkap ke penangkap lainnya sebenarnya menghadapi kesulitan pada awalnya karena ikanikan hasil tangkapan purse seine tersebut berukuran kecil. Pada saat itu, pada umumnya nelayan melakukan pemindahan ikan dari kapal penitip ke penerima titipan dengan cara menimba. Cara ini, selain memakan waktu yang relatif lama juga menyebabkan kerusakan fisik ikan karena benturan antara alat penimba dengan ikan, disamping karena lamanya waktu pemindahan. Pendekatan teknis yang kemudian dikembangkan oleh nelayan adalah pemindahaan ikan antar kapal menggunakan 'blong', yaitu drum plastik berukuran 0.2-0.3 $\mathrm{m}^{3}$ (lihat Gambar 1). Dengan asumsi bahwa pada saat tertentu sebuah kapal penangkap akan menitipkan hasil penangkapan, sejak saat penangkapannya ikan-ikan ditempatkan dalam blong-blong berisi es curah yang disimpan di dalam palka. Nelayan menemukan bahwa pendekatan ini memungkinkan pepindahan ikan secara lebih cepat dan mengurangi kerusakan akibat benturan fisik antara ikan dengan alat penimba.

Pemindahan antar kapal menggunakan blong dapat dilakukan dengan dua cara, yaitu menggantung dan mendorong blong pada tali yang dibentangkan diantara kedua kapal atau dengan memikulnya di atas papan yang diletakkan untuk menghubungkan kedua kapal. Untuk perikanan purse seine yang berbasis di Juwana, cara pemindahan ini dapat terlaksana pada hampir semua situasi cuaca karena lokasi penangkapan berada di perairan-perairan dengan ombak yang tidak terlalu besar. Lebih lanjut, pada saat dimana ombak berkembang besar pun, nelayan masih memiliki peluang untuk melaksanakan pemindahan dengan cara tersebut karena nelayan di lokasi-lokasi penangkapan tersebut hampir selalu memiliki kesempatan untuk merapat ke pulau dan untuk mendapatkan lokasi yang terlindung dari ombak. Merapat ke pulau dan melakukan pemindahan biasanya memakan waktu tidak lebih dari satu jam.

Selisih pendapat yang berpotensi muncul dalam transaksi penitipinan hasil tangkapan dapat diperkecil dengan adanya sistem komunikasi radio dari kapal dengan pengurus kapal di darat. Dengan kesepakatan detil yang telah dikomunikasikan melalui sistem radio sejak saat pemindahan ikan dari kapal penitip, selisih pendapat dapat dihindari. Dalam hal ini, detil-detil yang disepakati melalui komunikasi radio menyangkut jumlah dan spesifikasi ikan, identitas kapal yang menerima titipan, maupun biaya yang disepakati (pada umumnya sekitar $10 \%$ dari hasil lelang) untuk titip-menitip

\footnotetext{
1) Laba kotor/Gross profit = total penerimaan/Total revenue-total biaya operasional/Total operation cost
} 

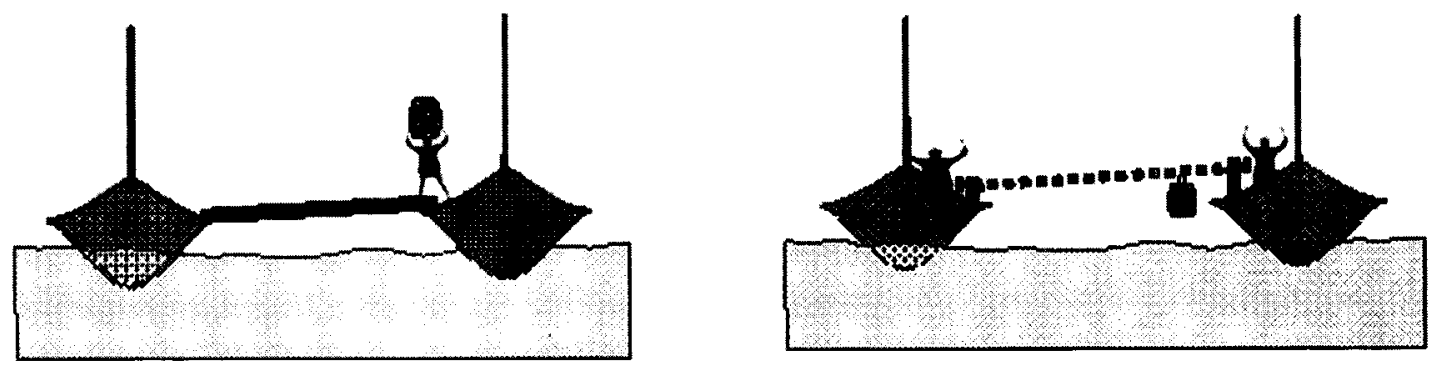

Gambar 1. Mekanisme pemindahan ikan menggunakan 'blong'.

Figure 1. Fish transfer mechanism by using 'blong' device.

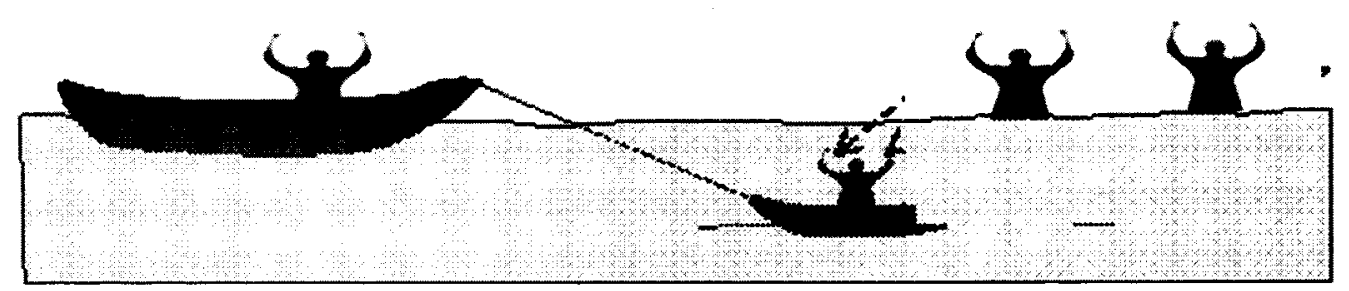

Gambar 2. Mekanisme pemindahan ikan berukuran besar (tuna) di Cilacap.

Figure 2. Big fish (tuna) transfer mechanism at Cilacap.

tersebut. Pengurus atau pemilik kapal akan mengawasi dan melakukan penyelesaian transaksi di darat pada saat pembongkaran ikan oleh kapal penerima titipan di tempat pendaratan.

Di Cilacap, dengan lingkungan teknis yang berbeda, titip muatan ikan dipraktekkan oleh nelayan dengan cara yang berbeda dengan yang dilakukan oleh nelayan purse seine di Juwana. Di Cilacap, titip muatan dilakukan oleh penangkap tuna yang menggunakan alat long line. Karena ukurannya yang besar dan harganya yang relatif tinggi, beberapa kendala teknis sebagaimana dihadapi oleh nelayan purse seine Juwana tidak dialami oleh nelayan long line di Cilacap. Praktek titip muatan untuk tuna di Cilacap ini terdorong terutama oleh tuntutan mempertahankan kualitas ikan, yang sebagian besar ditujukan untuk pasaran internasional.

Kondisi ombak yang relatif lebih besar dibanding ombak di perairan dimana kapal-kapal purse seine Juwana melakukan penangkapan, menyebabkan mekanisme pemindahan ikan tuna di Cilacap berkembaang berbeda dengan mekanisme pemindahan yang terjadi di Juwana. Ombak besar di Lautan Hindia, dimana kapal-kapal long line Cilacap melakukan penangkapan, tidak memungkinkan kapal penitip dan penerima titipan untuk saling merapat. Dengan kendala teknis seperti itu, mekanisme yang kemudian berkembang adalah pemindahan ikan dalam kondisi kapal yang tidak saling merapat tetapi dibantu oleh perahu kecil yang menjadi media pemindahan bagi kapal penitip dan kapal penerima titipan (Gambar 2). Dari kapal penitip, ikan dipindahkan satu persatu secara manual kepada perahu media tersebut hingga batas kapasitasnya. Dengan kendali berupa tali yang diikatkan pada sisi depan dan belakangnya, perahu tersebut ditarik di antara kapal penitip dan penerima titipan. Dengan mekanisme seperti itu, perahu kecil yang telah penuh dengan ikan titipan ditarik kearah kapal penitip untuk secara manual pula diangkat satu persatu ke kapal penerima titipan tersebut.

Pemindahan satu persatu seperti dipraktekkan oleh nelayan long line di Cilacap ini, selain dimungkinkan juga merupakan sesuatu yang memang seharusnya dilakukan. Di satu sisi, hal tersebut dimungkinkan karena korbanan waktu, tenaga dan biaya yang terkait dengan cara pemindahan satu persatu cukup terkompensasi oleh terjaganya mutu dari komoditas yang memiliki nilai ekonomis tinggi, suatu hal yang berbeda dengan konteks perikanan purse seine, dimana harga ikan rata-rata tidak terlalu tinggi. Di sisi lain, hal tersebut merupakan keharusan karena pemindahan secara serentak dikhawatirkan akan 
secara fisik merusak ikan sehingga menurunkan kualitas dan mengurangi peluang untuk mempertahankannya sebagai komoditas ekspor.

Untuk komoditas tuna ini, titip muatan pada umumnya dilakukan antar kapal dalam satu armada. Menurut para pemilik kapal, hal ini terutama terkait asumsi bahwa naluri bisnis akan mendorong para $A B K$ dalam satu kelompok armada (meskipun berbeda kapal) untuk bertanggung jawab terhadap kualitas setiap potong ikan karena kualitas rata-rata ikan dari kelompok mereka akan berpengaruh terhadap performa usaha mereka secara bersama-sama. Sebaliknya, naluri bisnis tersebut akan mendorong ABK dari kelompok armada lain untuk bertindak sebaliknya. Untuk mendukung pernyataan ini, para pemilik mencontohkan kecenderungan yang ada, dimana pertukaran $A B K$ antar kapal sedapat mungkin mereka batasi karena para pemilik ingin semaksimal mungkin menjaga setiap rahasia bisnis dari kelompok armadanya. Dengan motivasi yang sedikit berbeda dibanding yang terjadi pada kasus purse seine Juwana, nelayan pada umumnya tidak menerapkan ongkos angkut/biaya titip yang terlalu kaku; besaran biaya angkut biasanya hanya diistilahkan sebagai "ongkos capek", yang besarnya sangat bervariasi.

Di Pekalongan, titip muatan antar kapal dilakukan oleh nelayan purse seine dan nelayan gill net, dengan mekanisme yang sama dengan yang terjadi di Juwana, tetapi pada umumnya seperti yang berkembang di Cilacap dipraktekkan hanya oleh kapal-kapal dalam satu armada. Karena terjadi hanya dalam kelompok-kelompok armada yang sama, di Pekalongan tidak ditemukan adanya keseragaman biaya angkut yang berlaku umum.

Selain mekanisme penitipan bebas sebagaimana terjadi di Juwana, di Pekalongan berkembang sistem petitipan yang lebih terencana, yang diadopsi oleh sebuah kelompok armada ${ }^{2}$ di lokasi tersebut. Dalam perencanaan tersebut, sejumlah kapal penangkap diberangkatkan secara bergiliran ke lokasi lokasi penangkapan (fishing ground) tertentu, dengan jarak antar kapal berkisar antara 30-60 mil. Selama berada di fishing ground, masing-masing dari kapal tersebut mempertahankan komunikasi radio satu dengan yang lain. Pada saat kapal-kapal tertentu telah memenuhi target tangkapan, komunikasi dilakukan di antara semua kapal untuk menentukan titik tertentu di sekitar fishing ground, untuk melakukan penitipan muatan dari kapal yang akan tinggal untuk sementara waktu ke kapal yang akan menuju ke lokasi pendaratan. Dengan latar belakang kondisi fisik lingkungan perairan yang sama dengan fishing ground kapalkapal Juwana, proses pemindahan yang dilakukan oleh nelayan Pekalongan berkembang sama dengan yang terjadi di Juwana (Gambar 1). Dengan jarak antar kapal sejauh 30-60 mil, waktu yang dibutuhkan untuk pemindahan berkisar antara 2-3 jam.

Karena berada dalam satu sistem manajemen (satu armada), pemilik kapal dapat melengkapi pengaturan titip muatan dengan pengaturanpengaturan lain. Misalnya, mengupayakan kesegaran es yang digunakan sebagai media pendingin hasil tangkapan, kapal-kapal penangkap diberangkatkan secara bergiliran setiap 2-3 hari, dengan membawa perbekalan es yang diperuntukkan tidak hanya untuk kapal yang bersangkutan, melainkan juga untuk dibagi-bagikan kepada kapal-kapal lain di fishing ground. Dengan pengaturan ini, kualitas es dapat terjaga dan beban muatan yang terlalu besar (terkait dengan jumlah es yang berlebihan) dapat dihindari. Seperti yang terjadi pada titip muatan dalam satu armada di Cilacap, biaya titip ikan dan pemasokan es ditetapkan tidak terlalu besar, yaitu $3 \%$ dari hasil lelang. Tabel 1 menunjukkan gambaran aspek teknis sistim titip muatan di tiga lokasi penelitian.

Dari kajian terhadap aspek teknis di ketiga lokasi kasus tersebut di atas, dapat dipetik beberapa pelajaran. Di antara pelajaran penting yang dapat dipetik tersebut adalah bahwa dalam lingkungan fisik yang tidak terlalu mendukung seperti ombak yang besar, teknik-teknik yang relatif memakan korbanan waktu, tenaga, maupun biaya perlu dikembangkan karena dalam konteks usaha secara keseluruhan teknik-teknik tersebut memungkinkan diperolehnya manfaat yang lebih besar kepada nelayan. Pelajaran penting lain yang juga dapat dipetik adalah bahwa pada saat korbanan tersebut terlalu besar dibanding manfaat yang diperoleh, nelayan termotivasi untuk mengembangkan teknik-teknik yang lebih efisien, sesuai kondisi teknis yang melingkunginya. Dari kedua pelajaran penting tersebut, dapat dimunculkan sebuah pelajaran baru, yang dapat dimanfaatkan untuk pengembangan sistem titip secara lebih luas. Pelajaran baru yang pertama adalah tentang perlunya mengkombinasikan berbagai pengalaman di berbagai kasus untuk memperoleh teknik-teknik yang lebih efektif dan efisien; dalam penelitian ini, salah satu contohnya adalah kombinasi

\footnotetext{
2) Kelompok Bintang Mas Wiguna Grup adalah sebuah perusahaan keluarga yang bergerak di bidang penangkapan dengan armada berkekuatan $36 \mathrm{kapal}$ yang berukuran 50-80GT/Bintang Mas Wiguna Group is a family scale industry with of 36 ship of 50-80 GT each
} 
Tabel 1. Aspek teknis sistim titip muatan di Juwana, Cilacap dan Pekalongan

Table 1. Technical aspect systems of entrusted-catch shipping in Juwana, Cilacap and Pekalongan

\begin{tabular}{|c|c|c|c|}
\hline \multirow{2}{*}{ No } & \multicolumn{3}{|c|}{ Lokasi/Location } \\
\hline & Juwana & Cilacap & Pekalongan \\
\hline$\overline{1}$ & $\begin{array}{l}\text { Praktek titip muatan dilakukan } \\
\text { oleh nelayan purse seine dalam } \\
\text { satu pemilik maupun pemilik } \\
\text { kapal yang berbedalEntrusted- } \\
\text { catch shipping practices was } \\
\text { used by purse seine fisherman in } \\
\text { one same owner and others }\end{array}$ & $\begin{array}{l}\text { Praktek titip muatan } \\
\text { dilakukan oleh nelayan tuna } \\
\text { long line dalam satu pemilik } \\
\text { kapal/Entrusred-cath } \\
\text { shipping practices was used } \\
\text { by tuna long line fisherman } \\
\text { only in one ownertrusred-cath } \\
\text { shipping practices was used } \\
\text { by tuna lona line fisheman }\end{array}$ & $\begin{array}{l}\text { Praktek titip muatan } \\
\text { dilakukan oleh nelayan purse } \\
\text { seine dan nelayan gill net } \\
\text { dalam satu pemilik } \\
\text { kapal/En trusred-cath } \\
\text { shipping practices was used } \\
\text { by purse seine and gill net } \\
\text { fisherman only in one owner }\end{array}$ \\
\hline
\end{tabular}

2 Biaya titip muatan yang Biaya titip muatan besarnya disepakati $10 \%$ dari hasil lelang sangat bervariasi/Catch shipikan yang dititipkan/Catch shipping cost agreement is $10 \%$ of auction

3 Mekanisme pemindahan ikan dalam kondisi kapal merapat dengan menggunakan blong yang digantung pada tali yang dibentangkan diantara kedua kapal atau dengan memikul blong diatas papan yang diletakkan untuk menghubungkan kedua kapal tersebut/Fish transfer mechanism among ships is under close-distance condition using drums which is hung on to the string-line of each ship or by camying drums above connected board of among ships

\begin{abstract}
Biaya titip muatan besarnya cukup bervariasi/Catch shipping cost is vamied
\end{abstract}

Mekanisme pemindahan ikan sama dengan Juwana/Fish transfer mechanism is same as at Juwana antara penggunaan blong (atau wadah yang lebih sesuai) dengan cara pemindahan menggunakan perahu pembantu, untuk lebih mempertahankan kualitas ikan tuna dan meningkatkan efisiensi. Pelajaran baru yang kedua adalah tentang perlunya menciptakan kondisi seperti pada manajemen dalam satu armada; hal ini terutama penting dalam kaitannya dengan pengaturan-pengaturan komplemen yang dapat meningkatkan efisiensi (seperti dicontohkan pada kasus Pekalongan) dan untuk menyelaraskan dengan perundangan yang ada. Keselarasan dengan perundangan yang ada yang dimaksud adalah yang terkait dengan peraturan yang tidak memungkinkan transfer muatan antar kapal berbeda armada, karena dapat digolongkan sebagai transhipment, yang dilarang.

\section{Aspek Profitabilitas}

Salah satu hal terpenting yang perlu diperhatikan dalam mempertimbangkan pengembangan praktek titip muatan dalam rangka penyehatan usaha perikanan tangkap adalah profitabilitas. Hal ini terutama benar karena, seperti terungkap pada pendahuluan, alasan utama pengkajian praktek titip muatan yang dilaporkan dalam 
Tabel 2. Analisis finansial parsial pada praktek titip muatan di Juwana

Table 2. Partial financial analysis of entrusted-catch shipping practices in Juwana

\begin{tabular}{|c|c|c|c|c|c|c|}
\hline \multirow{3}{*}{$\begin{array}{l}\text { Kategoril } \\
\text { Category }\end{array}$} & \multirow{2}{*}{\multicolumn{2}{|c|}{$\begin{array}{l}\text { Tanpa penitipan } \\
\text { hasil tangkap/ } \\
\text { Without entrusted- } \\
\text { catch shipping }\end{array}$}} & \multicolumn{4}{|c|}{$\begin{array}{l}\text { Dengan penitipan hasil tangkap/ } \\
\text { With entrusted-catch shipping }\end{array}$} \\
\hline & & & \multicolumn{2}{|c|}{ Penitip/Shipper } & \multicolumn{2}{|c|}{$\begin{array}{l}\text { Penerima titipan/ } \\
\text { Catch shipper }\end{array}$} \\
\hline & $\begin{array}{l}\text { Fisik/ } \\
\text { Physical }\end{array}$ & ( Rp) & $\begin{array}{l}\text { Fisik/ } \\
\text { Physical }\end{array}$ & $(R p)$ & $\begin{array}{l}\text { Fisik/ } \\
\text { Physical }\end{array}$ & (Rp) \\
\hline $\begin{array}{l}\text { Penerimaan/ } \\
\text { Revenue: }\end{array}$ & & & & & & \\
\hline $\begin{array}{l}\text { Produk kualitas } \\
\text { rendah/L ow quality } \\
\text { product }\end{array}$ & $\begin{array}{l}10.800 \mathrm{~kg} \mathrm{x} \\
\text { Rp. } 3000 / \mathrm{kg}\end{array}$ & 32.400 .000 & 0 & & 0 & \\
\hline $\begin{array}{l}\text { Produk kualitas } \\
\text { baik/Good quality } \\
\text { product }\end{array}$ & $\begin{array}{l}7.200 \mathrm{~kg} \mathrm{x} \\
\text { Rp. } 7000 / \mathrm{kg}\end{array}$ & 50.400 .000 & $\begin{array}{l}18.000 \mathrm{~kg} \mathrm{x} \\
\text { Rp. } 7.000 / \mathrm{kg}\end{array}$ & 126.000 .000 & $\begin{array}{l}9.000 \mathrm{~kg} \mathrm{X} \\
\operatorname{Rp} 7.000 / \mathrm{kg}\end{array}$ & 63.000 .000 \\
\hline $\begin{array}{l}\text { Ongkos } \\
\text { penitipan/Catch } \\
\text { shipping cost }\end{array}$ & & 0 & & 0 & $\begin{array}{c}10 \% \times 9.000 \mathrm{~kg} \\
\times \mathrm{Rp} 7.000 / \mathrm{kg}\end{array}$ & 6.300 .000 \\
\hline $\begin{array}{l}\text { Pengurangan hari } \\
\text { layar/Day trip } \\
\text { reduction }\end{array}$ & & 0 & & 0 & & 18.000 .000 \\
\hline $\begin{array}{l}\text { Total penerimaan } \\
\text { Total revenue }\end{array}$ & & 82.800 .000 & & 126.000 .000 & & 87.300 .000 \\
\hline $\begin{array}{l}\text { Biaya } \\
\text { operasional/ } \\
\text { Operational cost: }\end{array}$ & & & & & & \\
\hline $\begin{array}{l}\text { Perbekalan/ } \\
\text { Provisions }\end{array}$ & & 16.500 .000 & & 16.500 .000 & & 16.500 .000 \\
\hline $\begin{array}{l}\text { Solarl } \\
\text { Diesel fuel }\end{array}$ & $\begin{array}{l}9.000 \operatorname{Itr} x \\
\text { Rp. } 1.650 / \text { tr }\end{array}$ & 14.850 .000 & $\begin{array}{l}9.000 \operatorname{Itr} x \\
\text { Rp. } 1.650 / \mathrm{tr}\end{array}$ & 14.850 .000 & $\begin{array}{l}9.000 \mathrm{Itr} x \\
\text { Rp. } 1.650 / \mathrm{tr}\end{array}$ & 14.850 .000 \\
\hline $\begin{array}{l}\text { Es balok//ce } \\
\text { block }\end{array}$ & $\begin{array}{c}35 \text { ton } x \\
\text { Rp. } 141.000 / \text { ton }\end{array}$ & 4.935 .000 & $\begin{array}{l}35 \tan x \\
\text { Rp. } 141.000 / \text { ton }\end{array}$ & 4.935 .000 & $\begin{array}{c}35 \text { ton } x \\
\text { Rp. } 141.000 / \text { ton }\end{array}$ & 4.935 .000 \\
\hline $\begin{array}{l}\text { Garam } / \\
\text { Salt }\end{array}$ & $\begin{array}{c}7 \text { ton } x \\
\text { Rp. } 245.000 / \text { ton }\end{array}$ & 1.715 .000 & $\begin{array}{c}7 \text { ton } x \\
\text { Rp. } 245.000 / \text { ton }\end{array}$ & 1.715 .000 & $\begin{array}{c}7 \text { ton } x \\
\text { Rp. } 245.000 / \text { ton }\end{array}$ & 1.715 .000 \\
\hline $\begin{array}{l}\text { Cadangan/ } \\
\text { Reserve }\end{array}$ & & 2.000 .000 & & 2.000 .000 & & 2.000 .000 \\
\hline
\end{tabular}


Tabel 2. Analisis finansial parsial pada praktek titip muatan di Juwana (lanjutan)

Table 2. Partial financial analysis of entrusted-catch shipping practices in Juwana (continued)

\begin{tabular}{|c|c|c|c|c|c|c|}
\hline \multirow{3}{*}{$\begin{array}{l}\text { Kategori } \\
\text { Category }\end{array}$} & \multirow{2}{*}{\multicolumn{2}{|c|}{$\begin{array}{l}\text { Tanpa penitipan } \\
\text { hasil tangkapl } \\
\text { Without entrusted } \\
\text { catch shipping }\end{array}$}} & \multicolumn{4}{|c|}{$\begin{array}{l}\text { Dengan penitipan hasil tangkap/ } \\
\text { With entrusted-catch shipping }\end{array}$} \\
\hline & & & \multicolumn{2}{|c|}{ Penitip/Shipper } & \multicolumn{2}{|c|}{$\begin{array}{l}\text { Penerima titipanl } \\
\text { Catch shipper }\end{array}$} \\
\hline & $\begin{array}{l}\text { Fisikd } \\
\text { Physical }\end{array}$ & ( Rp) & $\begin{array}{l}\text { FisikJ } \\
\text { Physical }\end{array}$ & (Rp) & $\begin{array}{c}\text { FisikJ } \\
\text { Physical }\end{array}$ & (Rp) \\
\hline $\begin{array}{l}\text { Biaya penitipan/ } \\
\text { Shipping cost }\end{array}$ & & 0 & $\begin{array}{l}10 \% \times 9.000 \mathrm{~kg} \\
\times \mathrm{Rp} 7.000 / \mathrm{kg}\end{array}$ & 6.300 .000 & & 0 \\
\hline $\begin{array}{l}\text { Total biaya } \\
\text { operasional } \\
\text { Operational total } \\
\text { cost }\end{array}$ & & 40.000 .000 & & 46.300 .000 & & 40.000 .000 \\
\hline $\begin{array}{l}\text { Laba kotorl } \\
\text { Gross profit }\end{array}$ & & 42.800 .000 & & 79.700 .000 & & 47.300 .000 \\
\hline
\end{tabular}

Catatan/Remark:

Kalkulasi di atas didasarkan pada asumsi-asumsi yang disepakati oleh responden, sebagai berikut/The above calculation is based on assumptions approved by respondents, as follows:

- Hasil tangkapan durasi layar normal $=4$ lobang/trip $(=18.000 \mathrm{Kg}) /$ Total catchment of normal trip periode $=4$ hole/ trip $(=18.000 \mathrm{Kg})$

- Hasil tangkapan durasi layar pendek $=2$ lobang/trip $(=9.000 \mathrm{Kg}) /$ Total catchment of short trip periode 2 hole/trip $(=9.000 \mathrm{Kg})$

- Kapal penangkap dengan durasi pendek dapat menghemat biaya operasional sebanyak Rp 18 juta/Short trip periode ship save the expence up to could Rp 18 million

- Semua harga yang dipergunakan adalah harga yang berlaku pada saat penelitian/All prices the utilized is price applying at the (time) of research.

- Sebagian pemilik menyerahkan semua penerimaan dari hasil penitipan kepada $A B K$, sedang pemilik lain memberlakukan pembagian $30 \%$ untuk pemilik dan $70 \%$ untuk ABK/Some owners gave all catch shipping revenues to $A B K$, while other shared $30 \%$ to owner and $70 \%$ to $A B K$

makalah ini adalah adanya penurunan keuntungan yang terkait dengan bertambahnya durasi layar ratarata kapal penangkap. Berikut ini adalah analisis profitabilitas dari praktek titip muatan di ketiga lokasi kasus.

Di Juwana, praktek titip muatan yang terjadi di antara para nelayan purse seine berhasil meningkatkan proporsi hasil tangkapan berkualitas baik, harga ikan, dan pendapatan nelayan. Hasil wawancara dengan pejabat TPI Juwana menyebutkan bahwa sebelum adanya sistem titip muatan total produksi hasil tangkapan dalam 1 trip yang bermutu baik hanya sekitar 7.2 ton $(40 \%)$ sedangkan sisanya sebanyak 10.8 ton dalam kondisi rusak. Kondisi tersebut sangat merugikan nelayan karena perbedaan antara harga ikan berkualitas baik dan ikan rusak sangat besar; pada saat penelitian dilakukan, harga rata-rata ikan berkualitas baik adalah Rp. $7.000,-/ \mathrm{kg}$ sedangkan ikan bermutu rendah/rusak adalah Rp. $3.000,-/ \mathrm{kg}$. Selanjutnya disebutkan bahwa dengan praktek titip muatan yang dilakukan oleh para nelayan, poporsi ikan rusak dapat ditekan hingga mendekati nol persen. Dengan perbaikan kualitas tersebut, nelayan memperoleh kenaikan keuntungan sebagaimana ditunjukkan pada Tabel 2.

Dari Tabel 2, dapat disimpulkan bahwa praktek titip muatan dapat kenaikan pendapatan nelayan yang cukup signifikan. Untuk kapal penitip, peningkatan laba kotor mencapai Rp 36,9 juta/trip (86\%) sedangkan bagi penerima titipan, peningkatan laba kotor mencapai Rp 4,5 juta (10\%). 
Tabel 3. Analisis finansial parsial pada praktek titip muatan di Cilacap

Table 3. Partial financial analysis of entrusted-catch shipping practices in Cilacap

\begin{tabular}{|c|c|c|c|c|c|c|}
\hline \multirow{3}{*}{$\begin{array}{l}\text { Kategori/ } \\
\text { Category }\end{array}$} & \multirow{2}{*}{\multicolumn{2}{|c|}{$\begin{array}{l}\text { Tanpa penitipan } \\
\text { hasil tangkap/ } \\
\text { Without entrusted- } \\
\text { catch shipping }\end{array}$}} & \multicolumn{4}{|c|}{$\begin{array}{l}\text { Dengan penitipan hasil tangkap/ } \\
\text { With entrusted-catch shipping }\end{array}$} \\
\hline & & & \multicolumn{2}{|c|}{ Penitip/Shipper } & \multicolumn{2}{|c|}{$\begin{array}{l}\text { Penerima titipan/ } \\
\text { Catch shipper }\end{array}$} \\
\hline & $\begin{array}{l}\text { Fisik/ } \\
\text { Physical }\end{array}$ & ( Rp) & $\begin{array}{l}\text { Fisik/ } \\
\text { Physical }\end{array}$ & (Rp) & $\begin{array}{l}\text { Fisik/ } \\
\text { Physical }\end{array}$ & (Rp) \\
\hline $\begin{array}{l}\text { Penerimaanl } \\
\text { Revenue: }\end{array}$ & & & & & & \\
\hline $\begin{array}{l}\text { Produk kualitas } \\
\text { rendah/Low } \\
\text { quality product }\end{array}$ & $\begin{array}{c}14.000 \mathrm{~kg} \mathrm{x} \\
\text { Rp. } 11.000 / \mathrm{kg}\end{array}$ & 154.400 .000 & $\begin{array}{c}6.000 \mathrm{~kg} \mathrm{x} \\
\operatorname{Rp} 11.000 / \mathrm{kg}\end{array}$ & 66.000 .000 & $\begin{array}{c}2.000 \mathrm{~kg} \mathrm{x} \\
\operatorname{Rp} 11.000 / \mathrm{kg}\end{array}$ & 22.000 .000 \\
\hline $\begin{array}{l}\text { Produk kualitas } \\
\text { baik/G ood quality } \\
\text { product }\end{array}$ & $\begin{array}{c}6.000 \mathrm{~kg} \mathrm{x} \\
\text { Rp. } 22.500 / \mathrm{kg}\end{array}$ & 135.400 .000 & $\begin{array}{c}14.000 \mathrm{~kg} \mathrm{x} \\
\mathrm{Rp} 22.500 / \mathrm{kg}\end{array}$ & 315.000 .000 & $\begin{array}{c}8.000 \mathrm{~kg} \mathrm{x} \\
\mathrm{Rp} 22.500 / \mathrm{kg}\end{array}$ & 180.000 .000 \\
\hline $\begin{array}{l}\text { Ongkos penitipan/ } \\
\text { Catch shipping } \\
\text { cost }\end{array}$ & & 0 & & 0 & & 10.000 .000 \\
\hline $\begin{array}{l}\text { Pengurangan hari } \\
\text { layar/Day trip } \\
\text { reduction }\end{array}$ & & 0 & & 0 & & 125.000 .000 \\
\hline $\begin{array}{l}\text { Total penerimaan } \\
\text { Total revenue }\end{array}$ & & 289.000 .000 & & 381.000 .000 & & 315.000 .000 \\
\hline $\begin{array}{l}\text { Biaya } \\
\text { operasional/ } \\
\text { Operational cost: }\end{array}$ & & & & & & \\
\hline $\begin{array}{l}\text { Perbekalan/ } \\
\text { Provisions }\end{array}$ & & 185.000 .000 & & 185.000 .000 & & 185.000 .000 \\
\hline $\begin{array}{l}\text { Solar/ } \\
\text { Diesel fuel }\end{array}$ & $\begin{array}{c}57 \text { drum } x \\
\text { Rp. } 350.000 / \text { drum }\end{array}$ & 19.950 .000 & & 19.950 .000 & & 19.950 .000 \\
\hline $\begin{array}{l}\text { Es balok/ } \\
\text { Ice block }\end{array}$ & $\begin{array}{l}1.000 \text { balok } x \\
\text { Rp. } 10.000 / k g\end{array}$ & 10.000 .000 & & 10.000 .000 & & 10.000 .000 \\
\hline $\begin{array}{l}\text { Umpan lemuru/ } \\
B \text { ait of lemuru }\end{array}$ & $\begin{array}{c}5.000 \mathrm{~kg} \mathrm{x} \\
\operatorname{Rp} 3.000 / \mathrm{kg}\end{array}$ & 15.000 .000 & & 15.000 .000 & & 15.000 .000 \\
\hline $\begin{array}{l}\text { Umpan layang/ } \\
\text { Bait of layang }\end{array}$ & $\begin{array}{l}3.000 \mathrm{~kg} \mathrm{x} \\
\mathrm{Rp} 6.250 / \mathrm{kg}\end{array}$ & 18.750 .000 & & 18.750 .000 & & 18.750 .000 \\
\hline
\end{tabular}


Tabel 3. Analisis finansial parsial pada praktek titip muatan di Cilacap (lanjutan)

Table 3. Partial financial analysis of entrusted-catch shipping practices in Cilacap (continued)

\begin{tabular}{|c|c|c|c|c|c|c|}
\hline \multirow{3}{*}{$\begin{array}{l}\text { Kategori/ } \\
\text { Category }\end{array}$} & \multirow{2}{*}{\multicolumn{2}{|c|}{$\begin{array}{l}\text { Tanpa penitipan } \\
\text { hasil tangkap/ } \\
\text { Without entrusted- } \\
\text { catch shipping }\end{array}$}} & \multicolumn{4}{|c|}{$\begin{array}{l}\text { Dengan penitipan hasil tangkap/ } \\
\text { With entrusted-catch shipping }\end{array}$} \\
\hline & & & \multicolumn{2}{|c|}{ Penitip/Shipper } & \multicolumn{2}{|c|}{$\begin{array}{l}\text { Penerima titipan/ } \\
\text { Catch shipper }\end{array}$} \\
\hline & $\begin{array}{l}\text { Fisik/ } \\
\text { Physical }\end{array}$ & ( Rp) & $\begin{array}{l}\text { Fisik/ } \\
\text { Physical }\end{array}$ & (Rp) & $\begin{array}{l}\text { Fisik/ } \\
\text { Physical }\end{array}$ & (Rp) \\
\hline $\begin{array}{l}\text { Biaya penitipan/ } \\
\text { Shipping cost }\end{array}$ & & 0 & & 10.000 .000 & & \\
\hline $\begin{array}{l}\text { Total biaya } \\
\text { operasional } \\
\text { Operational total } \\
\text { cost }\end{array}$ & & 248.700 .000 & & 258.700 .000 & & 248.700 .000 \\
\hline $\begin{array}{l}\text { Laba kotorl } \\
\text { Gross profit }\end{array}$ & & 40.300 .000 & & 122.300 .000 & & 66.300 .000 \\
\hline
\end{tabular}

Catatan/Remark:

Kalkulasi di atas didasarkan pada asumsi-asumsi yang disepakati oleh responden, sebagai berikut/The above calculation is based on assumptions approved by respondents, as follows:

- Hasil tangkapan durasi layar normal $=20.000 \mathrm{Kg} /$ Total catchment of normal trip periode $=20.000 \mathrm{Kg}$

- Hasil tangkapan durasi layar pendek $=10.000 \mathrm{Kg} /$ Total catchment of short trip periode $=10.000 \mathrm{~kg}$

- Pada durasi pendek $20 \%$ hasil berkualitas rendah; pada durasi normal tanpa menitip muatan $70 \%$ berkualitas rendah sedangkan durasi normal dengan menitip muatan $30 \%$ hasil berkualitas rendah $/ 20 \%$ of total short trip periode catchment is law quality; $70 \%$ of total normal trip periode catchment without catch-shipping is low quality while only $30 \%$ with catch-shipping is low quality.

- Kapal penangkap dengan durasi pendek dapat menghemat biaya operasional sebanyak kurang lebih Rp 125 juta/Short trip periode ships could save the expences up to 125 million

- Biaya penitipan (yang diistilahkan sebagai ongkos cape diberlakukan sekitar 10 juta)/Shipping cost ("Named as "tried cost") is around 10 million

- Semua harga yang dipergunakan adalah harga yang berlaku pada saat penelitian/All prices are the price at research periode

- Penerimaan dari hasil penitipan diperlakukan sebagai pendapatan dari tangkapan sendiri, yang akan diperhitungkan dalam bagi hasil/Revenue of catch-shipping was considered as own revenue which would be calculated on sharring.

Seperti halnya pada perikanan purse seine di Juwana, praktek titip muatan juga terbukti mampu meningkatkan pendapatan nelayan pada perikanan longline di Cilacap. Dalam kasus ini, titip muatan dilakukan oleh kapal-kapal longline berukuran 30$40 \mathrm{GT}$, yang dalam operasinya membawa sekitar 40 ABK dan berlayar selama 3 hingga 4 bulan untuk mencapai lokasi-lokasi jauh, termasuk perairan di sekitar Christmas Island. Perbekalan yang diperlukan untuk operasi tersebut mencapai Rp 185 juta, sangat besar apabila dibandingkan dengan penerimaan yang diperoleh karena hari layar panjang tersebut menyebabkan kerusakan ikan dalam jumlah yang cukup besar.

Dengan adanya praktek titip muatan, prosentase ikan berkualitas baik meningkat lebih dari dua kali lipat, kenaikan pendapatan dalam praktek titip muatan terkait dengan perbaikan kualitas, yang berimbas pada peningkatan harga, tuna ekspor. Sebelum titip muatan dipraktekkan di kalangan nelayan, rata-rata hanya $30 \%$ hasil memenuhi standar kualitas ekspor, yang memiliki harga rata- 
Tabel 4. Analisis finansial parsial pada praktek titip muatan di Pekalongan

Table 4. Partial financial analysis of entrusted-catch shipping practices in Pekalongan

\begin{tabular}{|c|c|c|c|c|c|c|}
\hline \multirow{3}{*}{$\begin{array}{l}\text { Kategori/ } \\
\text { Category }\end{array}$} & \multirow{2}{*}{\multicolumn{2}{|c|}{$\begin{array}{l}\text { Tanpa penitipan } \\
\text { hasil tangkap/ } \\
\text { Without entrusted- } \\
\text { catch shipping }\end{array}$}} & \multicolumn{4}{|c|}{$\begin{array}{l}\text { Dengan penitipan hasil tangkap/ } \\
\text { With entrusted-catch shipping }\end{array}$} \\
\hline & & & \multicolumn{2}{|c|}{ Penitip/Shipper } & \multicolumn{2}{|c|}{$\begin{array}{l}\text { Penerima titipan/ } \\
\text { Catch shipper }\end{array}$} \\
\hline & $\begin{array}{l}\text { FisikJ } \\
\text { Physical }\end{array}$ & ( Rp) & $\begin{array}{c}\text { FisikJ } \\
\text { Physical }\end{array}$ & (Rp) & $\begin{array}{c}\text { Fisikl } \\
\text { Physical }\end{array}$ & (Rp) \\
\hline $\begin{array}{l}\text { Penerimaan/ } \\
\text { Revenue: }\end{array}$ & & & & & & \\
\hline $\begin{array}{l}\text { Produk kualitas } \\
\text { rendah/Low } \\
\text { quality product }\end{array}$ & $\begin{array}{l}12.000 \mathrm{~kg} \mathrm{x} \\
\mathrm{Rp} 3.500 / \mathrm{kg}\end{array}$ & 42.000 .000 & 0 & & 0 & \\
\hline $\begin{array}{l}\text { Produk kualitas } \\
\text { baik Good quality } \\
\text { product }\end{array}$ & $\begin{array}{c}8.000 \mathrm{~kg} \mathrm{x} \\
\mathrm{Rp} .7000 / \mathrm{kg}\end{array}$ & 56.000 .000 & $\begin{array}{l}20.000 \mathrm{~kg} \mathrm{x} \\
\mathrm{Rp} .7 .000 / \mathrm{kg}\end{array}$ & 140.000 .000 & $\begin{array}{l}10.000 \mathrm{~kg} \mathrm{x} \\
\mathrm{Rp} 7.000 / \mathrm{kg}\end{array}$ & 70.000 .000 \\
\hline $\begin{array}{l}\text { Ongkos } \\
\text { penitipan/Catch } \\
\text { shipping cost }\end{array}$ & & 0 & & 0 & $\begin{array}{c}10 \% \times 10.000 \mathrm{~kg} \\
\times \mathrm{Rp} 7.000 / \mathrm{kg}\end{array}$ & 7.000 .000 \\
\hline $\begin{array}{l}\text { Pengurangan hari } \\
\text { layar/Day trip } \\
\text { reduction }\end{array}$ & & 0 & & 0 & & 15.000 .000 \\
\hline $\begin{array}{l}\text { Total penerimaan } \\
\text { Total revenue }\end{array}$ & & 98.000 .000 & & 140.000 .000 & & 92.000 .000 \\
\hline $\begin{array}{l}\text { Biaya } \\
\text { operasional/ } \\
\text { Operational cost: }\end{array}$ & & & & & & \\
\hline $\begin{array}{l}\text { Perbekalan/ } \\
\text { Provisions }\end{array}$ & & 10.000 .000 & & 10.000 .000 & & 10.000 .000 \\
\hline $\begin{array}{l}\text { Solarl } \\
\text { Diesel fuel }\end{array}$ & $\begin{array}{l}10.000 \operatorname{ltr} x \\
\text { Rp. } 1.650 / \operatorname{ltr}\end{array}$ & 16.500 .000 & & 16.500 .000 & & 16.500 .000 \\
\hline $\begin{array}{l}\text { Es balok/ } \\
\text { lce block }\end{array}$ & 35 ton & 5.600 .000 & & 5.600 .000 & & 5.600 .000 \\
\hline $\begin{array}{l}\text { Garam/ } \\
\text { Salt }\end{array}$ & 10 ton & 2.200 .000 & & 2.200 .000 & & 2.200 .000 \\
\hline $\begin{array}{l}\text { Cadangan/ } \\
\text { Reserve }\end{array}$ & & 0 & & & & \\
\hline
\end{tabular}


Tabel 4. Analisis finansial parsial pada praktek titip muatan di Pekalongan (lanjutan)

Table 4. Partial financial analysis of entrusted-catch shipping practices in Pekalongan (continued)

\begin{tabular}{|c|c|c|c|c|c|c|}
\hline \multirow{3}{*}{$\begin{array}{l}\text { Kategori/ } \\
\text { Category }\end{array}$} & \multirow{2}{*}{\multicolumn{2}{|c|}{$\begin{array}{l}\text { Tanpa penitipan } \\
\text { hasil tangkapl } \\
\text { Without entrusted- } \\
\text { catch shipping }\end{array}$}} & \multicolumn{4}{|c|}{$\begin{array}{l}\text { Dengan penitipan hasil tangkapl } \\
\text { With entrusted-catch shipping }\end{array}$} \\
\hline & & & \multicolumn{2}{|c|}{ Penitip/Shipper } & \multicolumn{2}{|c|}{$\begin{array}{l}\text { Penerima titipan } \\
\text { Catch shipper }\end{array}$} \\
\hline & $\begin{array}{c}\text { Fisik } \\
\text { Physical }\end{array}$ & ( Rp) & $\begin{array}{l}\text { FisikJ } \\
\text { Physical }\end{array}$ & (Rp) & $\begin{array}{c}\text { FisikJ } \\
\text { Physical }\end{array}$ & $(R p)$ \\
\hline $\begin{array}{l}\text { Biaya penitipan/ } \\
\text { Shipping cost } \\
\text { Total biaya } \\
\text { operasional } \\
\text { Operational total } \\
\text { cost }\end{array}$ & & 33.300 .000 & $\begin{array}{c}10 \% \times 10.000 \mathrm{~kg} \times \\
\mathrm{Rp} 7.000 / \mathrm{kg}\end{array}$ & 7.000 .000 & & 33.300 .000 \\
\hline $\begin{array}{l}\text { Laba kotorl } \\
\text { Gross profit }\end{array}$ & & 64.700 .000 & & 99.700 .000 & & 58.700 .000 \\
\hline
\end{tabular}

Catatan/Remark:

Kalkulasi di atas didasarkan pada asumsi-asumsi yang disepakati oleh responden, sebagai berikut/The above calculation is based on assumptions approved by respondents, as follows:

- Hasil tangkapan durasi layar normal $20.000 \mathrm{~kg} /$ Total catch of normal trip periode $20.000 \mathrm{~kg}$

- Hasil tangkapan durasi layar pendek $10.000 \mathrm{~kg} /$ Total catch of short trip periode $10.000 \mathrm{~kg}$

- Kapal penangkap dengan durasi pendek dapat menghemat biaya operasional sebanyak Rp 15 juta/Short trip periode ship could save the expences up to 15 million

- Semua harga yang dipergunakan adalah harga yang berlaku pada saat penelitian/All prices are price at research periode

- Sebagian pemilik menyerahkan semua penerimaan dari hasil penitipan kepada $A B K$, sedang pemilik lain memberlakukan pembagian $30 \%$ untuk pemilik dan $70 \%$ untuk ABK/Some owners gave all shipping revenue to $A B K$, while others shared $30 \%$ to owners and $70 \%$ to $A B K$

rata sebesar $\mathrm{Rp} 22.500,-1 \mathrm{~kg}$; selebihnya dikategorikan berkualitas lokal dengan harga rata-rata $\mathrm{Rp} 11.000$,$/ \mathrm{kg}$. Akibat adanya praktek titip muatan, jumlah ikan yang didaratkan dengan kualitas ekspor bisa mencapai $70 \%-80 \%$. Tabel 3 menunjukkan gambaran peningkatan keuntungan yang diperoleh nelayan yang mempraktekkan titip muatan di lokasi tersebut.

Pada kasus ketiga, di Pekalongan, perbaikan pendapatan terkait dengan tambahan keuntungan yang diperoleh dari perbaikan kualitas secara signifikan. Titip muatan pada kasus ini diterapkan antar kapal dalam satu armada ${ }^{3}$. Sebelum adanya praktek titip, sekitar $50 \%$ dari hasil tangkapan rusak, sedangkan setelah adanya praktek tersebut, kerusakan hasil tangkapan dapat ditekan hingga hanya mendekati $0 \%$. Berdasarkan hasil wawancara dengan pemilik armada kapal yang mempraktekkan titip muatan di lokasi tersebut, diperoleh gambaran tambahan keuntungan seperti terlihat pada Tabel 4. Pengamatan pelengkap dalam penelitian ini juga menunjukkan bahwa selain mampu menciptakan peluang peningkatan keuntungan usaha dan dapat diterapkan dalam keterbatasan teknis lokal, praktek-praktek titip sebagaimana terjadi di masing-masing lokasi kasus juga berkembang karena dukungan faktor sosial setempat. Hal ini dapat dicontohkan dari berkembang dan tidak berkembangnya suatu varian praktek titip tertentu, misalnya berkembangnya 
praktek titip antar armada di Juwana, yang hanya terjadi di dalam satu armada di Pekalogan.

Di Pekalongan, sistem titip muatan yang hanya berlaku di antara nelayan satu pemilik sangat erat hubungannya dengan rendahnya kepercayaan di antara nelayan berbeda pemilik. Dari wawancara kelompok dengan sejumlah nelayan yang dihadirkan secara acak, diperoleh gambaran bahwa iklim persaingan yang tinggi mengakibatkan timbulnya rasa curiga yang kuat di antara sesama nelayan. Diistilahkan oleh nelayan dalam diskusi tersebut, "bahkan titip korek tidak akan terjadi, apalagi titip ikan". Hal ini berbeda dengan kondisi sosial para nelayan purse seine di Juwana. Salah satu faktor yang dapat menjelaskan perbedaan tersebut adalah adanya hubungan historis yang terjalin lama di antara para nelayan Juwana, sebuah kondisi yang berbeda dengan hubungan sosial di antara nelayan di Pekalongan. Konfirmasi dengan pejabat TPI menunjukkan bahwa hampir $100 \%$ nelayan Juwana merupakan nelayan yang berasal dari wilayah sekitar; sebaliknya, sebagian besar nelayan di Pekalongan berasal dari wilayah-wilayah lain di Pantura.

Hasil pengamatan aspek sosial di Pekalongan dan Juwana tersebut konsisten dengan hasil pengamatan di Cilacap. Dalam kasus di Cilacap ini, diperoleh informasi bahwa pemilik kapal berasal dari berbagai lokasi, termasuk beberapa wilayah di Sumatera. Wawancara dengan para pemilik menunjukkan bahwa sejauh ini tidak ada keinginan dari masing-masing di antaranya untuk melakukan komunikasi ataupun kerjasama karena sejauh ini tidak ada satu alasan pun yang dapat diacu untuk melakukan kerjasama yang dengan resiko yang dapat ditolerir. Tidak adanya tawaran kerjasama dari pemilik lain dipersepsikan oleh pemilik armada sebagai ketidaksiapan pihak lain untuk melakukan kerjasama secara terbuka. Akibatnya, semua pemilik armada long line di lokasi kasus ini mengambil opsi tindakan untuk hanya melaksanakan kerjasama di antara kapal-kapal dalam satu armada.

\section{KESIMPULAN DAN IMPLIKAS|}

Munculnya berituk-bentuk praktek titip muatan di lokasi-lokasi kasus dalam penelitian ini, yaitu Juwana (Pati), Cilacap dan Pekalongan, dapat dikaitkan dengan adanya dorongan faktor ekonomis, yang didukung oleh kemudahan teknis dan kondisi sosial setempat. Dibandingkan dengan rata-rata pendapatan nelayan dalam kondisi perikanan yang telah mendekati atau melampaui overfishing, praktek titip muatan dapat memperbaiki pendapatan yang terkait dengan kenaikan keuntungan sebesar $10-90 \%$.

Salah satu implikasi kebijakan sehubungan hasil penelitian ini adalah adanya peluang untuk mengintroduksikan praktek titip ini di lokasi-lokasi lain yang menghadapi masalah overfishing, terlebih setelah adanya kenaiknan harga BBM secara berturut-turut pada $t$ ahun 2005. Namun demikian, hasil penelitian ini juga menunjukkan bahwa pengembangan sistem titip muatan di lokasi-lokasi lain tersebut harus didahului paling tidak dengan kajian aspek teknis dan sosial, yang diperlukan untuk mendasari penyesuaian-penyesuaian pelaksanaannya. Sebagaimana diperoleh dari hasil penelitian ini, penyesuaian-penyesuaian ini misalnya terkait dengan mekanisme transfer muatan di laut, yang harus mempertimbangkan kondisi ombak, karakteristik fisik ikan, nilai ekonomis ikan, dsb.

\section{DAFTAR PUSTAKA}

Apriliani, T. dan A.H. Purnomo. 2005. Komparasi Tekno Finansial Teknologi Pendinginan Ikan Untuk Kapal Pengangkut.

Hernanto, F. 1998. I/mu Usahatani. Penerbit Swadaya. Jakarta. p. 200-222.

HNSI (Himpunan Nelayan Seluruh Indonesia). 2005. Keberlanjutan Usaha Perikanan Tangkap Skala Kecil Pasca Kenaikan BBM. Makalah disampaikan pada Pertemuan Pembahasan Keberlanjutan Usaha Perikanan Tangkap Pasca Kenaikan Harga BBM, Ditjen Tangkap, Jakarta 20 Oktober 2005.

Riyanto B. 1995. Dasar-dasar Pembelanjaan Perusahaan. Yayasan Badan Penerbit Gajah Mada. Yogyakarta. p. 35 - 51.

Nazir M. 1985. Metode Penelitian. PT. Ghalia Indonesia. Jakarta. p. 325-382.

Sisdjatmiko. 1990. Kajian Dasar Pengantar Teori Ekonomi Mikro. Rineka Cipta. Jakarta. 61 pp.

Suboko, B. 2005. Solusi Pengembangan usaha Perikanan Tangkap Pasca Kenaikan BBM. Makalah disampaikan pada Pertemuan Pembahasan Keberlanjutan Usaha Perikanan Tangkap Pasca Kenaikan Harga BBM, Ditjen Tangkap, Jakarta 20 Oktober 2005 
